\title{
Poverty levels and children's health status: study of risk factors in an urban population of low socioeconomic level*
}

\section{Nível de pobreza e estado de saúde das crianças: um estudo de fatores de risco em população urbana de baixo nível socioeconômico}

\author{
Roberto M.S. Issler, Elsa R.J. Giugliani, Guilherme T. Kreutz, Clarice F. Meneses, Elisa B. \\ Justo, Valerie M. Kreutz e Milton Pires \\ Departamento de Pediatria e Puericultura da Faculdade de Medicina da Universidade Federal do Rio \\ Grande do Sul. Porto Alegre, RS - Brasil
}

\begin{abstract}
To test the hypothesis that the low socioeconomic population living is shanty towns in Porto Alegre presents different levels of poverty which are reflected on its health status, a cross-sectional study was designed involving 477 families living in Vila Grande Cruzeiro, Porto Alegre, Brazil. The poverty level of the families was measured by using an instrument specifically designed for poor urban populations. Children from families living in extreme poverty (poorest quartile) were found to have higher infant mortality rate, lower birth weights, more hospitalizations, and higher malnutrition rates, in addition to belonging to more numerous families. Thus, the shanty town population of Porto Alegre is not homogeneous, and priority should be given to the more vulnerable subgroups.
\end{abstract}

Diagnosis of health situation. Health status indicators. Child health.

\begin{abstract}
Resumo
Para testar a hipótese de que a população de baixo nível socioeconômico apresenta diferentes níveis de pobreza que repercutem em seu estado de saúde, foi realizado estudo transversal envolvendo 477 famílias de uma população urbana pobre residente na Vila Grande Cruzeiro, em Porto Alegre, RS, Brasil. O nível de pobreza dessas famílias foi medido por meio de um instrumento especialmente elaborado para populações urbanas pobres. Crianças oriundas de famílias vivendo em extrema pobreza (quartil inferior) apresentaram maior taxa de mortalidade infantil, menor peso de nascimento, maior número de internações hospitalares e maiores índices de desnutrição, além de pertencerem a famílias mais numerosas. A população de baixo nível socioeconômico mostrou-se heterogênea em relação a diferentes indicadores de saúde. Concluiu-se que a identificação de subgrupos mais vulneráveis numa população permite concentrar as ações de saúde entre os mais necessitados.
\end{abstract}

Diagnóstico da situação de saúde. Indicadores de saúde. Saúde infantil.

\footnotetext{
* Based on master thesis "Níveis de pobreza e sua repercussão no estado de saúde de populações urbanas de baixa renda: um estudo em Porto Alegre, RS", by Roberto Mário S. Issler, presented to the "Universidade Federal do Rio Grande do Sul", 1993.

Correspondence to: Roberto Mario Silveira Issler - Departamento de Pediatria e Puericultura da Faculdade de Medicina da Universidade Federal do Rio Grande do Sul. Rua Ramiro Barcelos, 2350 - 10 $0^{\circ}$ andar - 90035-003 Porto Alegre, RS - Brasil. Fax: E-mail:

Received on 23.10.1995. Reviewed on 6.7.1996. Approved on 16.7.1996.
} 


\section{INTRODUCTION}

The health-disease process cannot be considered separately from the position an individual occupies in the biological, historical, or socioeconomic milieu. A relationship between poverty and deficient health has been observed throughout history, children being especially vulnerable to the deleterious effects of poverty and ignorance. When compared to children from privileged families, poor children present higher mortality ${ }^{10,13,24}$, are more frequently ill $^{11,15,24}$, are born with a lower weight ${ }^{4,25}$ and are more frequently malnourished $^{1,9,24}$. The mechanisms by which poverty affects the health status are diverse and not fully understood. It is known that there is a chain of different factors such as environmental and social conditions, behaviors and habits, exposure to preventive or medical care, psychological and immunological alterations, among others, which may interact through unknown paths ${ }^{23}$. Thus, individuals from the same families and communities would be expected to be at different levels of risk of becoming ill or dying even when sharing the same environment.

In Brazil, more than half the children and adolescents live in poverty and more than $25 \%$ live in extreme poverty ${ }^{7}$. Even though we know that poverty is a risk factor for greater morbidity and mortality, the limited resources available for health promotion and protection programs require priority to be given to certain groups in terms of health actions even within the poor population. As a contribution to the identification of more vulnerable children in poor urban populations, the objective of the present study was to test the hypothesis that the poor population presents different poverty levels which are reflected in their respective health status.

\section{MATERIAL AND METHOD}

A cross-sectional study was designed using a target population consisting of children aged one to five years from families living in well delineated areas of extreme poverty located in Vila Grande Cruzeiro, Porto Alegre, a city of approximately 1.5 million inhabitants. Vila Grande Cruzeiro is located approximately $6 \mathrm{~km}$ from the center of town and has a population of 70,000 inhabitants, 57\% of whom living in 29 areas of extreme poverty. The sample for the present study consisted of approximately $10 \%$ of the target population $(n=477)$ selected in two stages: 1$)$ random selection of the areas to be visited; and 2) random selection of a child when the family had more than one in the age range considered. To complete the sample size, all dwellings in the first five clusters picked at random were visited. Of the 488 families eligible to participate in the study, only 11 were not included in the sample (four refusals and seven could not be contacted), with a total loss of $2.2 \%$.

After being located, the families were interviewed and the children selected were weighed on a portable scales and measured with a wooden anthropometer (for children up to two years of age) or with a metal measuring tape. Most of the interviews (94.5\%) were held with the mothers of the children. The following variables were studied: birth weight, hospitalization and nutritional status of the children selected, and number of births, deaths of children younger than one year, and family poverty level.

In most cases, birth weight was obtained from birth records while in only 72 families this was information obtained verbally. Information referring to number of births and deaths of children younger than one year was not obtained for 30 families because the children concerned did not live with their biological mothers and consanguineous siblings. For the classification of nutritional status, weight/age, height/age and weight/height indices were calculated using the NCHS standard ${ }^{16}$. Children presenting one or more indices below -2 standard deviations (SD) were considered to be malnourished.

The poverty level of the families was measured by the instrument used by Alvarez et al. ${ }^{3}$ in Santiago, Chile, and adapted to the Brazilian culture. This instrument assigns points for 13 items related to family constitution, educational level and activity of the parents, domicile and peridomicile conditions, and the existence of some particular possessions (Table 1). This is an instrument especially developed for low socioeconomic level urban populations and does not include family income among its items. Family income is extremely difficult to obtain in this type of population, due to the large proportion of individuals who work only sporadically. For purposes of statistical analysis, the study population was divided into quartiles according to the score obtained in the poverty level classification. The families belonging to the poorest quartile of the population were considered to be living in extreme poverty.

Statistical analysis was carried out using the SPSS package ${ }^{17}$. Cross-tabulations with chi-square test were used to compare proportions. Odds ratio with $95 \%$ confidence intervals were used as the measurement of the association between poverty level and outcome variables. Since race is described as being associated with birth weight ${ }^{20}$, this variable was taken into account in measuring the association between poverty level and birth weight. The level of significance was set at $5 \%$.

\section{RESULTS}

Table 2 presents some of the characteristics of the sample. There was no statistical difference in sex between the extremely poor and the others. As regards race, there were more negroid children than others among the poorest families. Age distribution 
Table1 - Itens in the socioeconomic classification for low income urban population (modified from Alvarez et $\mathrm{al}^{3}$ ).

1. Number of people living and sleeping in the house

1 - 4 people

5 - 8 people

9 - 12 people

13 - 15 people

15 or more people

2. Abandonment by the father

None

Partial

Total

3. Educational level (mother \& father)

8 th grade (complete highschool) or more

5 th to 7 th

4th grade completed (elementary school)

1 th to 3 th

Illiterate

4. Professional activity (mother \& father)

Small business owner

Regular employee

Occational jobs (cleaning, gardening)

Welfare supported/retired

Unemployed

5. House possession

Own

Rent

Loan

Squatter

Living in somebody else's home

6. Type of house

Brick, well built

Wood or mixed (wood and brick)

Very simple building (pieces of wood,

cardboard) with more than 2 rooms

Very simple building (as above),

with 1 or 2 rooms

7. Number of beds/person

$1 \mathrm{bed} /$ person

Less then bed/person

8. Water supply

Pumped, inside the house

Pumped, outside the house

Carried from some other place

9. Sewage disposal

City Sewage system

Latrine

Open field

10. Waste disposal

Home collection

Public waste disposal

Carried to other places

11. Electricity in the house

Individual supply

Shared with others

None

12. Kitchen

Complete room in the house

Part of another room in the house

13. Home goods

Refrigerator

TV set

Oven

Radio

Sum of home goods: 15 points

10 - 14 points

4 - 9 points

1 - 3 points

0 point
Table 2 - Distribution of the sample, according to gender, race and age. Vila Cruzeiro, Porto Alegre, RS, Brazil.

\begin{tabular}{lcccc}
\hline Characteristic & $\begin{array}{c}\text { Extremely } \\
\text { poor }(\%)\end{array}$ & $\begin{array}{c}\text { Poor } \\
(\%)\end{array}$ & X2 & $P$ \\
\hline Gender & & & 0.01 & 0.9081 \\
Female $(n=251)$ & 51.7 & 52.9 & & \\
Male $(n=226)$ & 48.5 & 47.1 & & \\
Race* & & & 8.92 & 0.0028 \\
Caucasoid & & & & \\
$\quad$ (n=240) & 37.9 & 54.4 & & \\
Negroid & 37.9 & 54.4 & & \\
$\quad$ (n=236) & 62.1 & 45.6 & & \\
Age distribuition & & & 11.14 & 0.0109 \\
$\quad$ (mo) & & & & \\
$12-23(n=115)$ & 24.1 & 24.1 & & \\
$24-35(n=129)$ & 32.8 & 25.2 & & \\
$36-47(n=123)$ & 14.7 & 24.2 & & \\
$48-59(n=110)$ & 28.4 & 24.3 & & \\
* Unknown for 1 child & & & &
\end{tabular}

also showed some statistically significant inequalities.

The effect of poverty level on the outcome variable is shown in Table 3. The mean birth weight of the children in the sample was $3,134 \mathrm{~g}(\mathrm{f} \pm 575 \mathrm{~g})$, with a $12.3 \%$ prevalence of low birth weight $(<2,500 \mathrm{~g})$. Although the difference was not statistically significant, children belonging to families living in extreme poverty tended to have a greater prevalence of low birth weight when compared to all others ( $16.8 \%$ and $10.9 \%$, respectively).

Thirty-seven percent of the children had been hospitalized at least once. Respiratory diseases and diarrhea were the most common causes of hospitalization (38.6\% and $24.9 \%$, respectively). Extremely poor children were hospitalized significantly more times $(\mathrm{OR}=1.6)$.

Each family reported, on average, 3.5 births, including stillborns, and $11.5 \%$ experienced the death of a child younger than 1 year. A positive association was detected between extreme poverty and more numerous families $(\mathrm{OR}=2.0)$ and between extreme poverty and deaths during the first year of life $(\mathrm{OR}=2.0)$.

There was a significant association between poverty level and children's nutritional status. Extreme poverty increased the odds of having low weight for age (3.8 times), low height for age (2.8 times) and low weight for height (12.9 times).

\section{DISCUSSION}

The present study showed that in a poor urban population sharing the same macroenvironment there is a social stratification which affects the health status of individuals, especially children. The instrument used 
Table 3 - Effect of poverty level on selected variables. Vila Cruzeiro, Porto Alegre, RS, Brazil.

\begin{tabular}{|c|c|c|c|c|c|}
\hline \multirow{3}{*}{ Variable } & \multicolumn{4}{|c|}{ Poverty level } & \multirow{3}{*}{$\begin{array}{c}\text { Odds ratio } \\
(95 \% \text { confidence interval }\end{array}$} \\
\hline & \multicolumn{2}{|c|}{ Extremely poor } & \multicolumn{2}{|c|}{ Poor } & \\
\hline & $\mathrm{n}$ & $(\%)$ & $\mathrm{n}$ & $(\%)$ & \\
\hline \multicolumn{6}{|l|}{ Birth weight } \\
\hline$\geq 2,500 \mathrm{~g}$ & 94 & $(83.2)$ & 320 & $(89.1)$ & 1.00 \\
\hline$<2,500 \mathrm{~g}$ & 19 & $(16.8)$ & 39 & $(10.9)$ & $1.54(0.85-2.82)^{*}$ \\
\hline \multicolumn{6}{|l|}{ Hospitalization } \\
\hline no & 62 & (53.9) & 234 & $(65.4)$ & 1.00 \\
\hline yes & 53 & $(46.1)$ & 124 & $(34.6)$ & $1.61(1.03-2.53)$ \\
\hline \multicolumn{6}{|c|}{ Number of children in he family } \\
\hline$\leq 3$ & 47 & $(44.3)$ & 208 & $(61.0)$ & 1.00 \\
\hline$>3$ & 59 & $(55.7)$ & 133 & $(39.0)$ & $1.96(1.23-3.12)$ \\
\hline \multicolumn{6}{|c|}{ Infant death in the family } \\
\hline no & 86 & $(81.1)$ & 306 & $(89.7)$ & 1.00 \\
\hline yes & 20 & $(18.9)$ & 35 & $(10.3)$ & $2.03(1.07-3.85)$ \\
\hline \multicolumn{6}{|c|}{ Nutritional status Weight/age } \\
\hline$>-2 \mathrm{SD}$ & 96 & (83.5) & 343 & $(95.0)$ & 1.00 \\
\hline$\leq-2 \mathrm{SD}$ & 19 & (16.5) & 18 & $(5.0)$ & $3.77(1.81-7.87)$ \\
\hline \multicolumn{6}{|l|}{ Height/age } \\
\hline$>-2 \mathrm{SD}$ & 84 & $(73.0)$ & 318 & $(88.3)$ & 1.00 \\
\hline$\leq-2 \mathrm{SD}$ & 31 & $(27.0)$ & 42 & (11.7) & $2.79(1.60-4.87)$ \\
\hline \multicolumn{6}{|l|}{ Weight/height } \\
\hline$>-2 \mathrm{SD}$ & 111 & $(96.5)$ & 359 & (99.7) & 1.00 \\
\hline$\leq-2 \mathrm{SD}$ & 4 & $(3.5)$ & 1 & $(0.3)$ & $12.90(1.37-307.08)$ \\
\hline
\end{tabular}

* Adjusted for race

to evaluate the level of poverty proved to be useful for the identification of families with a higher risk of having children with low birth weight, malnourished, and sick, with a consequently higher mortality rate.

The prevalence of low birth weight detected in the sample is certainly lower than its incidence in this population since only the children who survived the first year of life were investigated. It is known that infant mortality is higher among low birth weight children ${ }^{19}$. Even so, prevalence was much higher in the population studied if compared with official data for the city $(8.9 \%)^{2}$ or for the state $(9.9 \%)^{21}$ Stratification of this population by poverty level showed that the poorest individuals are at higher risk of having children with low birth weight, who consequently present cumulatively the deleterious effects of this condition such as malnutrition, chronic diseases and poorer school performance ${ }^{12,24}$. Barros et al. ${ }^{4}$, by stratifying a cohort of almost 6,000 children by family income, showed that in Brazil it is possible to obtain low birth weight indices similar to those of more developed countries. More privileged children presented an incidence of low birth weight of only $4.2 \%$, a little above that reported for Sweden ${ }^{6}$.

In the present study, hospitalization was used as an indicator of severe morbidity. The rate of hospitalization detected in the poor population of Vila
Cruzeiro was high when compared to the cohort of Pelotas, Brazil (36.7\% and 27.3\%, respectively), probably due to the lower socioeconomic level of the Vila Cruzeiro population. The frequency of hospital admissions would probably be even higher if the study had included all children and not only those who survived the first year of life. The association between poverty and hospitalization has been demonstrated by others. In a study carried out in S. Paulo, the poorest children had an incidence of hospital admission due to pneumonia 20 times higher than that of the most privileged children ${ }^{15}$. In the Pelotas study, the lower the family income the higher the percentage of children hospitalized due to diarrhea, respiratory infections and bronchospas ${ }^{24}$. The present study showed that children living in extreme poverty have a 1.6 times higher chance of being hospitalized. One of the factors leading to the more frequent hospitalization of the poorer Brazilian children is "social admission". Many times the physician indicates hospitalization for social reasons rather than of the severity of the disease since it is known that many poor families cannot care properly for a sick child or provide treatment at home.

Regarding the nutritional status, the children evaluated in the present study basically presented a 
chronic process of malnutrition, as revealed by the high indices of low height for age. The association between social, economic and environmental variables and the nutritional status of children younger than 5 years of age has been reported in many stu $\operatorname{dies}^{5,9,14,26}$. In the present study, children living in extreme poverty presented 3.7, 2.7 and 12.9 times greater probability of low weight for age, short height for age and low weight for height, respectively. The effects of this precarious nutritional status may be manifested throughout life and also be transmitted to the next generation. Children with nutritional deficiency may present poor school performance ${ }^{18}$ and, when they reach adulthood, may present limitations in physical capabilities due to their smaller body mass, with repercussions in terms of productivity ${ }^{22}$.

By implementing a series of measures that permitted greater access to family planning by the low income population, a decrease in family size has been observed among Brazilian families of low socioeconomic level ${ }^{8}$. The families classified as less poor in the present study, although living in shanty towns, had a reproductive pattern and birth rates close to those of more privileged families. However, the present study revealed that there are still parts of the population that should receive greater attention on the part the institutions which promote family planning. Indeed, the families living in extreme poverty continue to be the most numerous. There is evidence in the literature that when there is an abundance of food, family size has no effect on the health status of the children. If food is limited, children grow better when they do not have to share it with siblings ${ }^{27}$.

\section{REFERENCES}

1. AERTZ, D. R. G. C. Estudo do estado nutricional das crianças de Porto Alegre: uma contribuição ao entendimento do processo de desnutrição. Porto Alegre, 1992. [Dissertação de Mestrado - Universidade Federal do Rio Grande do Sul].

2. AERTZ, D. R. G. C. Relatório Preliminar SINASC. Porto Alegre. Centro de Documentação e Informação em Saúde, Secretaria Municipal da Saúde e Serviço Social de Porto Alegre, 1993.

3. ALVAREZ, M. L. et al. Mediciones del nivel socioeconomico bajo urbano en famílias con lactante desnutrido. Arch. Latinoamer. Nutr., 32:650-62, 1982.

4. BARROS, F. C. et al. Saúde perinatal em Pelotas, RS, Brasil: fatores sociais e biológicos. Rev. Saúde Pública, 18: 301-12, 1984.
Since the present study investigated the number of deaths of children of less than 1 year of age along the family histories, it cannot be categorically stated that there still exist differences in infant mortality rates in the urban shanty town population today. However, we may state that, over a given period of time, deaths of small children were more frequent among families living in extreme poverty. The greater prevalence of low birth weight, the larger number of hospitalizations, and the more precarious nutritional status of the children in these families suggest that differences in the pattern of infant mortality still exist in the poor urban population.

We are aware of the fact that the association between poverty level and the variables studied here is complex and dynamic. These variables are interrelated, often forming a vicious cycle that is extremely harmful to children's health. Since the differences observed in this study are the product of the inequalities of Brazilian society, only a change in the model of development of the country would guarantee a substantial improvement of the people's health profile. However, there are some interventions that, although they not solve the basic problem, may have an impact on the quality of individuals' lives. Giving priority to a certain population would be one means of attempting to decrease the results of social distortion. The method utilized in the present study to classify poverty levels proved to be useful for the identification of children at higher risk of becoming sick or dying and may contribute to directic basic health actions such as family planning, prenatal care and programs of nutritional rehabilitation for those who most need them.

5. BATROUNI, L. et al. Diferenciación de la situación nutricional del preescolar, segun niveles socioeconomicos en una zona marginal. Arch. Latinoamer. Nutr., 4:565-78, 1985.

6. ERICSON, A. E. et al. Birth weight distribution as an indicator of environmental effects on fetal development. Scand. J. Soc. Med., 15: 11-7, 1987.

7. FUNDAÇÃO IBGE. Crianças e adolescentes: indicadores sociais. Rio de Janeiro, 1989.

8. FUNDAÇÃO IBGE. Perfil estatístico de mães e crianças no Brasil: a situação da fecundidade, determinantes gerais e características de transição recente. Rio de Janeiro, 1988.

9. GIUGLIANI, E. R. J. et al. The malnourished children of the urban squatter families: a study in Porto Alegre, Brazil. J. Trop. Pediatr., 33:194-8, 1987. 
10. GUIMARÃES, J. J. L. \& FISCHMANN, A. Desigualdade na mortalidade infantil entre favelados e não favelados no município de Porto Alegre, Rio Grande do Sul, em 1980. Bol. Ofic. Sanit. Panamer., 101:19-35, 1986.

11. MACLURE, A. \& STEWART, G. T. Admission of children to hospitals in Glasgow: relation to unemployment and other deprivation variables. Lancet, 2: 682-5, 1984.

12. MCGAUHEY, P. J. et al. The social environment and vulnerability of low birth weight children: a socialepidemiological perspective. Pediatrics, 88:943-53, 1991.

13. MONTEIRO, C. A. et al. Mortalidade no primeiro ano de vida e a distribuição de renda e de recursos públicos de saúde. São Paulo, Brasil. Rev. Saúde Pública, 14: 515-39, 1980.

14. MONTEIRO, C. A. et al. Estudo das condições de saúde das crianças do município de São Paulo (SP), Brasil, 1984-85. II Antropometria nutricional. Rev. Saúde Pública, 20:446-53, 1986.

15. MONTEIRO, C. A. et al. Estudo das condições de saúde das crianças do Município de São Paulo (Brasil), 1984/1985. XI. Cobertura e qualidade de assistência materno-infantil. Rev. Saúde Pública, 22:170-8, 1988.

16. NATIONAL CENTER OF HEALTH STATISTICS. Growth curve for children birth-18 years. Hyasttsville, United States Department of Health, Education and Welfare, 1977. (NCHS - Publication no. 78).

17. NORUSIS, M. J. SPSS/PC+ for the IBM/ PC/XT/AT. Chicago, SPSS Inc, 1986.

18. POLLIT, E. Desnutrición y rendimiento escolar. In: Cuzminsky, M. Crescimiento y desarollo: hechos y tendencias. Washington, OPS, 1988. p. 324-48 (OPS Publicación Científica, 510).
19. PUFFER, R. \& SERRANO, C. V. Características de la mortalidad en la niñez. Washington, OPS, 1973. (OPS Publicación científica, 262)

20. SCHOENDORF, K. C. et al. Mortality among infants of black as compared with white college-educated parents. $N$. Engl. J. Med., 326:1522-6, 1992.

21. SECRETARIA DA SAÚDE E MEIO AMBIENTE DO RIO GRANDE DO SUL. A criança no Rio Grande do Sul: indicadores de saúde. Porto Alegre, 1990.

22. SPURR, G. B. Tamaño corporal, capacidad de realizar trabajos fisicos y productividad en el trabajo intenso: ?Es mejor más grande? In: Retraso del crescimiento lineal en los paises en vias de desarollo. New York, Ravem Press, 1987. p. 25-9.

23. STARFIELD, B. Effects of poverty on health status; Proceedings of the Annual Health Conference Children at Risk: Poverty and Health. New York, Academy of Medicine, 1991.

24. VICTORA, C. G. et al. ed. Epidemiologia da desigualdade: um estudo longitudinal de 6.000 crianças brasileiras. São Paulo, HUCITEC, 1988.

25. VICTORA, C. G. et al. Birthweight, socioeconomic status and growth of Brazilian infants. Ann. Hum. Biol., 14: 49-57, 1987.

26. VICTORA, C. G. et al. Risk factors for malnutrition in Brazilian children: the role of social and environmental variables. Bull. WHO, 64: 299-309, 1986.

27. WRAY, J. \& MAINE, D. Family spacing. In: Grant, J.P., ed. The State of the World's Children 1984. Oxford, Oxford University Press, 1983. p.92-100. 